\title{
Unifikacja i kodyfikacja wojskowej procedury karnej w II Rzeczypospolitej
}

I. W świadomości historyków prawa okres międzywojenny na ogół kojarzy się z budowaniem niemal od podstaw polskiego systemu prawnego. Wiemy wiele na temat funkcjonowania i dokonań Komisji Kodyfikacyjnej RP. Posiadamy również wiedzę na temat tego, co się nie udało przygotować przed wybuchem II wojny światowej, choć prace były zaawansowane, a ich efekty zaowocowały przyspieszeniem prac kodyfikacyjnych w początkach Polski Ludowej.

Na tym tle nasza znajomość dziejów ówczesnego prawodawstwa wojskowego nie wygląda już tak imponująco. Stosunkowo niedawno dzięki badaniom L. Kani pogłębiliśmy swoją wiedzę na temat wojskowego prawa karnego materialnego oraz organizacji i funkcjonowania wojskowego wymiaru sprawiedliwości. Wojskowe prawo karne procesowe było jednak dotychczas na ogół pomijane. Przyczyn takiego stanu rzeczy zapewne było wiele. Trudny dostęp do i tak niekompletnych materiałów archiwalnych oraz przekonanie o postępującym procesie integracji prawa wojskowego z powszechnym porządkiem prawnym po 1969 r., to tylko niektóre powody. Międzywojenna wojskowa procedura karna zasługuje jednak na opracowanie. Jest tak dlatego, że powstały w połowie lat trzydziestych kodeks wojskowego postępowania karnego stanowił nie tylko efekt ewolucji uregulowań prawa wojskowego, ale także przemian w obrębie procesu karnego w ogóle. Skutki tego procesu są widoczne po dzień dzisiejszy. Ich rozważenie będzie jednak możliwe tylko po uprzednim przedstawieniu genezy międzywojennych uregulowań procesowych. 
II. Chociaż u progu niepodległości, w zakresie standardów wojskowej procedury karnej wydarzyło się zbyt wiele, aby w ogóle myśleć o powrocie do rozwiązań osiemnastowiecznych, to jednak pojawił się pomysł, aby nawiązać do regulacji prawnych powstania styczniowego ${ }^{1}$. Adwokat i historyk Aleksander Kraushar na łamach „Kuriera Warszawskiego” z dnia 3 czerwca 1917 r. napisał: „Wobec przygotowań do organizacji wojska polskiego w Królestwie i do ustanowienia przepisów zabezpieczających porządek i karność w jego kadrach, zwrócono uwagę na brak kodeksu specjalnego, który by w tej mierze mógł służyć za wskazówkę poglądów i zasad sfer wojskowych polskich, w czasach niezbyt od nas odległych, na tę doniosłą sprawę. Wskazówka taka istnieje. Ostatnie przepisy, ustanowione dla wojska narodowego w roku 1863, ogłoszono drukiem za czasów dyktatury Traugutta i pod jego kierunkiem, z mocy dekretu Rządu Narodowego z dnia 30 lipca 1863 roku$^{2}$. Powtórzono je, $\mathrm{z}$ dodaniem przepisów proceduralnych wojskowych, z mocy dekretu tegoż Rządu d. 20 listopada 1863 roku, w odbitce, sporządzonej w Lipsku, stanowiącej dziś rzadkość bibliograficzną"3.

Ten ciekawy i patriotyczny pomysł abstrahował jednak całkowicie od ówczesnej sytuacji geopolitycznej. Większość żołnierzy polskich służyła bowiem w armiach posiadających już znacznie nowocześniejsze rozwiązania prawne, które pochodziły z przełomu XIX i XX w. Co więcej, to właśnie wywodzący się z armii niemieckiej i austro-węgierskiej oficerowie sądowi mieli stanowić trzon kadr formującego się sądownictwa wojskowego. Problemem wydawało się zatem nie tyle to, czy wybrać któryś z tych systemów prawnych, jako rozwiązanie unifikacyjne, ile to - który. Było jasne, że chaos prawny i niejednolitość są nie do przyjęcia na dłuższą metę. Kwestię tę dostrzegła już Tymczasowa Rada Stanu, która po interwencji płk. Kazimierza Sosnkowskiego, we wnioskach Wydziału Wykonawczego z dnia 26 czerwca 1917 r. stwierdziła, że ,istnienie dwóch wojskowych procedur karnych w Legionach [niemieckiej z 1898 r. i austriackiej 1912 r. - T.Sz.] wprowadza i utrwala podział formacji polskich sprzeczny z ich moralnością, narodową i historyczną jednością, uniemożliwiając kadrowe wykorzystanie całości dla celów budowy armii polskiej”4. Dlatego też postanowiono zwrócić się do władz cesarskich o pozwolenie, aby wszyscy żołnierze i oficerowie legionowi podlegali niemieckiej wojskowej procedurze karnej z 1 grudnia 1898 r., którą wraz z nie-

1 J. Daniec, Historia sądownictwa wojskowego, „Wojskowy Przegląd Prawniczy” (1928), nr 8-10, s. 9.

${ }^{2}$ Kodeks karny wojskowy dekretem Rządu Narodowego z dnia 30 lipca 1863 r. (Centralna Biblioteka Wojskowa, sygn. MG 261).

3 A. Kraushar, Archiwum dokumentów historyczno-prawnych z odleglejszej i mniej odległej przeszłości, Kodeks karny wojskowy i procedura karna z czasów powstania styczniowego 1863 roku, „Gazeta Sądowa Warszawska” (1917), nr 24, s. 261-262.

${ }^{4}$ Archiwum Akt Nowych [dalej AAN], Tymczasowa Rada Stanu, sygn. 24, mikrofilm B-7532. 
mieckim wojskowym kodeksem materialnym z 20 czerwca 1872 r. uznawano za odpowiednie prawo dla armii polskiej ${ }^{5}$. Jaki był odzew i czy w ogóle wystąpiono $\mathrm{z}$ taka propozycją, tego nie wiemy. Nie ulega jednak wątpliwości, że byłoby to w istocie rozwiązanie tymczasowe, dostosowane do warunków niedużej formacji wojskowej, a nie całej odradzającej się armii polskiej liczącej dziesiątki tysięcy żołnierzy, wywodzących się z różnych formacji wojskowych. Dlatego też wraz z postępującą reorganizacją i integracją polskich sił zbrojnych konieczne było uwzględnienie także innych systemów prawnych niż niemiecki ${ }^{6}$.

Pomysł Tymczasowej Rady Stanu odnośnie do unifikacji prawa wojskowego z uwzględnieniem wzorców niemieckich pokazuje jednak, że priorytetem była jednolitość ustawodawstwa karnego wojskowego, niezależnie od jego źródeł i bieżącej sytuacji politycznej. Nadal utrzymywał się w sądownictwie wojskowym znaczny partykularyzm prawny. Oprócz regulacji niemieckich i austriackich $\mathrm{w}$ formacjach polskich obowiązywały także przepisy francuskie ${ }^{7} \mathrm{i}$ rosyjskie ${ }^{8}$.

Wyjściem z tej kłopotliwej dla wojska sytuacji okazała się stopniowa unifikacja, dostosowana do realiów organizujących się sił zbrojnych. Należało bowiem uwzględnić zarówno względy kadrowe, jak i terytorialne, faktycznie funkcjonującego sądownictwa wojskowego. Rozwiązanie powyższe znalazło swoje odzwierciedlenie w dekrecie z 19 stycznia 1919 r. „Ustawa o tymczasowej organi-

${ }^{5}$ W celu spolszczenia powyższych ustaw powołano komisję przy Komisji Wojskowej Tymczasowej Rady Stanu w składzie: 1 delegat Komisji Wojskowej; 2 oficerów Sądu Polowego Komendy Legionów Polskich; 2 delegatów Departamentu sprawiedliwości.

${ }^{6}$ T. Wyszomirski, Pierwsze dni sądownictwa wojskowego w niepodległej Polsce, „Wojskowy Przegląd Prawniczy" (1938), nr 4, s. 2.

${ }^{7}$ Na podstawie art. 2 dekretu prezydenta Republiki Francuskiej z dnia 31 maja 1918 r., w armii polskiej we Francji obowiązywały postanowienia powyższego kodeksu z pewnymi zmianami o charakterze ustrojowym i organizacyjnym. Tak urządzona procedura karna wojskowa obowiązywała w sądownictwie polowym armii gen. Hallera do września 1919 r. (Pismo gen. J. Hallera do Naczelnego Dowództwa Wojsk Polskich z dnia 7 maja 1919 r., nr 18.J.M/II, w: Centralne Archiwum Wojskowe [dalej CAW], Naczelne Dowództwo Wojsk Polskich, Szefostwo Sądownictwa Polowego sygn. I.301.21.1); zob. także S.J. Nider, Organizacja wojskowego sadownictwa francuskiego i procedura. Sadownictwo wojskowe w armii polskiej we Francji, „Wojskowy Przegląd Prawniczy” (1929), nr 9-11, s. 50 i n.; M. Czyżak, Odrębność polskiego prawa karnego wojskowego wobec prawa karnego powszechnego, Warszawa 2010, s. 40; T. Rybicki, Sadownictwo polowe w latach wojny 1919-1921, „Wojskowy Przegląd Prawniczy” (1928), nr 8-10, s. 48).

${ }^{8}$ K. Grzybowski, Od uwłaszczenia do odrodzenia państwa, [w:] Historia państwa i prawa Pol$s k i$, red. J. Bardach, S. Grodziski, M. Senkowska-Gluck, t. IV, Warszawa 1982, s. 214; J. Nazarewicz, Wymiar sprawiedliwości w Czwartej Dywizji Strzelców Polskich na terytorium Rosji (sierpień 1918 - czerwiec 1919), „Wojskowy Przegląd Prawniczy” (1991), nr 1, s. 31-34; idem, Wymiar Sprawiedliwości w Piątej Dywizji Strzelców Polskich na Syberii (lipiec 1918 - maj 1920), „Wojskowy Przegląd Prawniczy" (1991), nr 2, s. 16-18; S. Lubodziecki, Rosyjskie sadownictwo wojskowe, Warszawa 1926, s. 2-8. 
zacji sądowej Wojska Polskiego"9. Akt ten powstał w Komisji Przygotowawczej ds. Sądownictwa Wojskowego w Ministerstwie Spraw Wojskowych. Jej przewodniczącym był gen. ppor. Jan Roszkowski. Głównym referentem projektu był mjr Jan Krzakowski ${ }^{10}$. Nazwa tego aktu, jak i jego moc wiążąca budziły uzasadnione wątpliwości. Konieczne było w przyszłości jej zastąpienie przez akt ustawowy ${ }^{11}$.

Niemniej jednak dekret z 19 stycznia wyznaczał nie tylko standardy wojskowego postępowania karnego, ale przede wszystkim kładł podwaliny jednolitego wojskowego wymiaru sprawiedliwości w Polsce po $1918 \mathrm{r}$. w ogóle ${ }^{12}$. Jego przyjęcie oznaczało także uznanie obowiązywania w Wojsku Polskim niemieckiej i austro-węgierskiej wojskowej procedury karnej, do których 20 lutego 1919 r. wydano przepisy przechodnie, dostosowujące je do polskich realiów ustrojowych i organizacyjnych ${ }^{13}$. $Z$ treści tych przepisów wynikały następujące okoliczności:

I. Austro-węgierska ustawa wojskowego postępowania karnego z dnia 5 lipca 1912 r. ${ }^{14}$ :

1) miała obowiązywać na obszarze krakowskiego i lubelskiego okręgu generalnego;

9 Dz. Rozk. Wojsk. z 1919 r. nr 11, poz. 393. „Ustawa” weszła w życie z dniem 1 marca 1919 r. na mocy dekretu z dnia 19 lutego 1919 r. o wprowadzeniu w życie Ustawy o tymczasowej organizacji sądowej Wojska Polskiego (Dz. Rozk. Wojsk. z 1919 r. nr 21, poz. 686); zob. także W. Makowski, Kodeks karny wojskowy z dodaniem ustaw i przepisów wprowadczych, przechodnich i uzupetniajacych oraz komentarzem, Warszawa 1921, s. 6-9. Gen. Józef Daniec określił dekret z dnia 19 stycznia 1919 r. o tymczasowej organizacji sądowej Wojska Polskiego „podwaliną ustroju sądownictwa wojskowego [...] Dalsze dekrety i rozporządzenia dotyczą zmian tylko tych urządzeń, które nie wytrzymały próby życiowej”(J. Daniec, Historia..., s. 11).

${ }^{10}$ Projekt ustawy o tymczasowej organizacji sądowej Wojska Polskiego z dnia 15 grudnia 1918 r. (Centralne Archiwum Wojskowe, Oddział VI Prawny, Ministerstwo Spraw Wojskowych, sygn. I.300.12.1).

${ }^{11}$ Protokół posiedzenia podkomisji ustawodawczej dla prawa formalnego z dnia 20 maja 1919 r. (CAW, Oddział VI Prawny, Ministerstwo Spraw Wojskowych, sygn. I.300.12.1, s. 1). Zob. także sprawozdanie stenograficzne z 80 posiedzenia Sejmu Ustawodawczego z dnia 29 lipca 1919 r., s. 51, (http://bs.sejm.gov.pl/, [dostęp: 20.01.2015]).

${ }_{12}$ T. Maresch, O wymiarze sprawiedliwości w Wojsku, (Polska odbitka z Revue Pénitentiaire de Pologne - The Polish Review of Penal Sciences), Warszawa 1938, s. 11.

13 Dz. Rozk. Wojsk. z 1919 r., nr 21, poz. 703 i 704.

${ }_{14}$ Dziennik Ustaw Państwa dla Królestw i Krajów w Radzie Państwa Reprezentowanych z 1912 r. poz. 130, s. 441 i nast., dostępny w Jagiellońskiej Bibliotece Cyfrowej pod adresem internetowym: http://jbc.bj.uj.edu.pl/dlibra/docmetadata?id=229085\&from=publication [dostęp: 20.11.2013]). Jak podaje Juliusz Makarewicz, przepisy austro-węgierskiej procedury karnej wojskowej do końca XIX w., a więc przed wydaniem ustawy z 1912 r., były wręcz nie do osiągnięcia przez kogoś kto nie był związany z audytoriatem. Nie były drukowane do powszechnego użytku ani dostępne w bibliotekach. Dopiero wydanie zbioru tych przepisów przez kpt. dr. J. Lelewera w 1901 w wersji ujednoliconej staraniami Ministerstwa wojny z 1884 r., stan ten odmieniło (J. Makarewicz, Prace rozproszone, t. 2: publikowane w latach 1902-1913, Lublin 2012, s. 81-84). 
2) wyrażenie „Wspólna Siła Zbrojna” obecne w jej tekście zastąpiono pojęciem „Wojsko Polskie”;

3) przez prawa przysługujące Panującemu należało rozumieć Najwyższą Władzę Państwową;

4) zamiast pojęcia „monarchia austro-węgierska” wprowadzono Państwo Polskie;

5) pojęcia „sądy brygady”, „sądy dywizji” i „Najwyższy Trybunał Wojskowy" zastąpiono odpowiednio nazwami sądy pułkowe, sądy okręgów generalnych i Naczelny Sąd Wojskowy;

6) wyroki sądów wojskowych miały być wydawane w imieniu Państwa Polskiego;

7) sprecyzowano właściwość Naczelnego Sądu Wojskowego, jako sądu I instancji w odniesieniu do dowódców okręgów generalnych, dowódców korpusów, szefów departamentów Ministerstwa Spraw Wojskowych (dalej: MSWojsk) oraz równorzędnych;

8) językiem urzędowym w sądach wojskowych miał być język polski.

II. Niemiecka ustawa wojskowego postępowania karnego z dnia 1 grudnia $1898 \mathrm{r}^{15}$.

1) miała obowiązywać na obszarze warszawskiego, łódzkiego i kieleckiego okręgu generalnego;

2) wyrażenie „Wspólna Siła Zbrojna” zastąpiono pojęciem „Wojsko Polskie”;

3) pojęcie „Rzesza” zastąpiono wyrażeniem „Państwo Polskie”;

4) uprawnienia Cesarza i Naczelnika Kontyngentu odniesiono do „Najwyższej Władzy Państwa";

5) kompetencje sądów wyższych i Sądu Rzeszy przejął Naczelny Sąd Wojskowy, natomiast organizacja i funkcjonowanie niemieckich sądów niższych, a więc sądów pułkowych i sądów wojskowych, pozostała nadal w mocy ze zmianami wynikającymi z ustawy o tymczasowej organizacji sądowej Wojska Polskiego;

6) językiem urzędowym w sądach wojskowych miał być język polski.

Na podstawie powyższego zestawienia możemy skonstatować, że w zakresie samej procedury nie dokonywano większych zmian. Ciężar rodzimej regulacji skoncentrowany był na kwestiach ustrojowych i organizacyjnych, które znalazły swoje uregulowanie przede wszystkim w dekrecie z dnia 19 stycznia.

Przepisy wskazanych procedur miały być stosowane „natychmiast”, jednak zastrzeżeniem, że dotychczasowe postępowania w każdej sprawie pozostawały w mocy. Z treści omówionych wyżej rozkazów kierownika Ministerstwa Spraw

${ }^{15}$ Niemiecka ustawa wojskowego postępowania karnego z dnia 1 grudnia 1898 r. wraz z ustawą wprowadzającą (tekst w języku polskim: Biblioteka Jagiellońska, sygn. II 717897, [b.w., b.r., b.ttum.]). 
Wojskowych płk. Jana Wroczyńskiego nie wynikało, co kryło się pod określeniami „natychmiast” oraz „dotychczasowe postępowania pozostają w mocy”. Można założyć, że „natychmiast” oznaczało z chwilą ogłoszenia, bez jakiegokolwiek vacatio legis, co w realiach wydarzeń początku 1919 r. byłoby jak najbardziej zasadne. Z kolei drugie pojęcie można interpretować dwojako, a mianowicie, że wcześniej wszczęte postępowania miały toczyć się zgodnie z procedurami stosowanymi do tego czasu albo w ten sposób, że nowe przepisy chwytają toczące się postępowania niejako „w locie”, jednak dotychczasowe czynności procesowe pozostają w mocy. Ta druga możliwość wydaje się najbardziej prawdopodobna nie tylko z powodu natury norm prawa procesowego, ale przede wszystkim z faktem, że celem wskazanych rozkazów było jak najszybsze opanowanie sytuacji w sądownictwie wojskowym, a nie przeciąganie niejednolitości ${ }^{16}$.

III. Dekret z 19 stycznia traktowano jako rozwiązanie przejściowe. Niezbędna była ustawa ustrojowa i proceduralna $\mathrm{z}$ prawdziwego zdarzenia dla całej armii. Z tego też powodu w Ministerstwie Spraw Wojskowych powołano komisję do opracowania prawa formalnego. W jej skład wchodzili: gen. ppor. Jan Roszkowski jako przewodniczący, mjr Witold Szulborski, mjr Artur Ganczarski, mjr Roman Wawrowski, mjr Emil Mecnarowski, kpt. Dudrewicz, radca Ministerstwa Sprawiedliwości Stanisław Śliwiński i Leon Barysz jako sekretarz ${ }^{17}$.

Z zachowanych protokołów wynika, że komisja zebrała się co najmniej trzykrotnie, a to 8, 20 i 31 maja 1919 r. Jej celem było przygotowanie jednolitej procedury karnej. Problemem uniemożliwiającym zajęcie się kwestiami proceduralnymi okazała się jednak nierozstrzygnięta nadal kwestia organizacji ustrojowej sądownictwa wojskowego, uregulowanego tymczasowo na mocy dekretu z dnia 19 stycznia $^{18}$. Dał o sobie znać również niewątpliwie partykularyzm prawny ziem byłych zaborów. Jak wynika bowiem z oświadczenia mjr. Romana Wawrowskiego, reprezentującego poznańskie środowisko prawników wojskowych, komisariat Rady Narodowej w Poznaniu wraz z tamtejszym Naczelnym Dowództwem, przygotował własny projekt ustroju i organizacji sądownictwa wojskowego, który przewidywał między innymi utworzenie sądów apelacyjnych i likwidację sędziów śledczych. Był on tym samym znacząco różny od tego przygotowywanego w ministerstwie, na którym jednak w pozostałym zakresie się wzorował. Co więcej, z Warszawy do innych dzielnic miały docierać sprzeczne sygnały odnośnie do planu organizacji sądownictwa wojskowego. Informowano między innymi, że

${ }^{16}$ L. Kania, Przestępstwa przeciwko obowiazkowi wojskowemu i dyscyplinie w polskim prawie karnym i praktyce sąów wojskowych w latach 1795-1945, Sulechów 2010, s. 156.

17 Protokół posiedzenia podkomisji ustawodawczej dla prawa formalnego z dnia 20 maja 1919 r. (CAW, Oddział VI Prawny, Ministerstwo Spraw Wojskowych, sygn. I.300.12.1, s. 1).

${ }^{18}$ Dz. Rozk. Wojsk. Wojsk z 1919 r., nr 11, poz. 393. 
na obszarze państwa będą nadal obowiązywać dwie wojskowe procedury karne, co miało sugerować, że niezbędne jest jedynie jednolite opracowanie zagadnień ustrojowych. Tymczasem z samego założenia powołania wskazanej wyżej komisji ministerialnej wynikało, że należy do niej przede wszystkim opracowanie przepisów proceduralnych. Projekt tych przepisów w znacznym zakresie rzeczywiście powstał ${ }^{19}$.

W Poznaniu tymczasem pracowano wyłącznie nad kwestiami ustrojowymi w przekonaniu, że na obszarze byłego zaboru pruskiego będzie obowiązywać niemiecka wojskowa procedura karna ${ }^{20}$. Sytuacja wydawała się patowa. Jak wynikało z oświadczenia mjr. Wawrowskiego, otrzymał on z Rady Narodowej polecenie przedstawienia „poznańskiego projektu” komisji sejmowej, obok projektu ministerialnego. Przewodniczący komisji ministerialnej gen. Roszkowski sprzeciwił się takiemu podejściu do prac legislacyjnych. Oświadczył ponadto, że przedstawianie dwóch projektów komisji jest niemożliwe, albowiem Minister Spraw Wojskowych nie wiedziałby, za którym ma się opowiedzieće ${ }^{21}$. W związku z tym wysunięto pomysł wspólnej reprezentacji „poznańsko-warszawskiej” w pracach nad tymczasową organizacją sądownictwa wojskowego. Ta propozycja została także odrzucona, tym razem ze względów politycznych i wizerunkowych, gdyż „wspólna reprezentacja” wskazywałaby na podziały wewnątrz armii, które należało niwelować, a nie podkreślać. Nie było zgody na swoisty „dwugłos” wojskowego środowiska prawniczego w sejmie (tak mjr A. Ganczarski i S. Śliwiński). Ostatecznie uznano, że kwestie sporne co do organizacji sądownictwa wojskowego należy uzgodnić w ramach komisji ministerialnej, tak aby wystąpić wobec ciała ustawodawczego z jednolitą propozycją, uwzględniającą „projekt poznański” i ,projekt warszawski”. Temu celowi służyło posiedzenie z dnia 31 maja $^{22}$.

Tym sposobem kwestie wojskowej procedury karnej zepchnięto na dalszy plan, pomimo sugestii gen. Roszkowskiego, aby w związku z patem ustrojowym zająć się procedurą, w której to dziedzinie dostrzegalna była możliwość porozumienia ponad podziałami. Było jednak jasne, że o przyszłej wojskowej procedurze karnej zadecyduje przyjęty system ustrojowo-organizacyjny sądownictwa wojskowego. Zwycięstwo wizji poznańskiej, a opierającej sądownictwo wojsko-

19 „Projekt ustawy wojskowego postępowania karnego tymczasowo w Wojsku Polskim obowiązującej” (CAW, Oddział VI Prawny, Ministerstwo Spraw Wojskowych, sygn. I.300.12.1).

${ }^{20}$ Protokół posiedzenia podkomisji ustawodawczej dla prawa formalnego z dnia 20 maja 1919 r. (ibidem).

${ }^{21}$ Protokół posiedzenia podkomisji ustawodawczej dla prawa formalnego z dnia 20 maja 1919 r. (CAW, Oddział VI Prawny, Ministerstwo Spraw Wojskowych, sygn. I.300.12.1).

22 Protokół posiedzenia komisji ministerstwa do opracowania wojskowego prawa formalnego z dnia 31 maja 1919 r. (CAW, Oddział VI Prawny, Ministerstwo Spraw Wojskowych, sygn. I.300.12.21). 
we na systemie apelacyjnym, oznaczałoby przyjęcie niemieckiego modelu postępowania karnego. Przychylenie się do zapatrywania „warszawsko-lubelskiego" opartego na systemie kasacyjnym, wiązałoby się z recepcją austriackich rozwiązań. Była jeszcze wciąż możliwa i trzecia droga, a mianowicie stworzenie procedury zupełnie od podstaw, która uzgadniałaby sporne kwestie, choć ze względu na przebieg wskazanych posiedzeń wydawało się to już wówczas coraz mniej prawdopodobne ${ }^{23}$.

Drugie ze wskazanych rozwiązań, już 20 maja okazało się bardziej prawdopodobne niż pozostałe. Jak wynika ze słów przewodniczącego gen. Roszkowskiego: „sądownictwo wojskowe powinno być szybkie i proste, a wprowadzenie instytucji apelacyjnej tylko je obciąży”. Co więcej, sam mjr Wawrowski nie wykluczał uzgodnienia stanowiska, wygłaszając następującą opinię: ,przypuszczam, iż zasady przyjęte w Poznaniu nie będą tak niewzruszalne, jeśli Poznań przyswoi sobie zasady postępowania kasacyjnego to niewątpliwie zgodzi się na zniesienie sądów apelacyjnych"24. Rozstrzygnięcie tych problemów miało nastąpić już jednak nie w komisji ministerialnej, a na forum Komisji Prawniczej Sejmu Ustawodawczego ${ }^{25}$.

IV. W dniu 29 lipca 1919 r. nastąpiło ogłoszenie ustawy „O tymczasowym sądownictwie wojskowym" ${ }^{26}$. Było to jedno z najistotniejszych wydarzeń w dziedzinie sądownictwa wojskowego okresu międzywojennego. Akt ten przesądził o tym, że w Wojsku Polskim obowiązywać będzie - w przeciwieństwie do powszechnego wymiaru sprawiedliwości - tylko jedna procedura karna wojskowa. Do tego właśnie momentu pozostawało kwestią otwartą, czy to miałaby być jedna z obcych procedur, czy też zupełnie nowa ustawa procesowa. $Z$ przedstawionych materiałów archiwalnych wyraźnie wynika, że noszono się także z zamiarem przygotowania rodzimej regulacji. Zwyciężyła jednak opcja przejęcia obcego prawa $\mathrm{z}$ odpowiednim jego dostosowaniem do warunków rodzimych. Była to droga unifikacyjna, zbliżona w swym kształcie do tej, jaką przewidywano dla sądownictwa powszechnego ${ }^{27}$. Droga jednak zakończona w wojsku sukcesem ${ }^{28}$.

${ }^{23}$ Projekt przepisów o środkach zaskarżenia, przyjmujący system apelacyjno-kasacyjny (ibidem).

${ }^{24}$ Protokół posiedzenia podkomisji ustawodawczej dla prawa formalnego z dnia 20 maja 1919 r. (CAW, Oddział VI Prawny, Ministerstwo Spraw Wojskowych, sygn. I.300.12.1, s. 9).

${ }_{25}$ Sprawozdanie posła A. Świdy z dnia 29 lipca 1919 r. (Sprawozdanie stenograficzne z 80 posiedzenia Sejmu Ustawodawczego, s. 51-53, http://bs.sejm.gov.pl/, [dostęp: 20.01.2015]).

${ }^{26}$ Dz. Pr. z 1919 r., nr 65, poz. 389.

27 Wystąpienie ministra sprawiedliwości prof. Wacława Makowskiego na konferencji posłów i prawników w Ministerstwie Sprawiedliwości, które odbyło się 6 grudnia 1922 r. (AAN, Biuro Sejmu R.P, Akta Komisji Prawniczej. Ustawodawstwo społeczne i sądowe w Polsce, opinie, uwagi 1922 rok, sygn. 67).

${ }^{28}$ A. Lityński, Dwa kodeksy karne 1932. W osiemdziesiąta rocznice, , Rocznik Administracji i Prawa" 12 (2012), s. 215. 
Najwyraźniej zdano sobie sprawę, że natychmiastowe przygotowanie od podstaw rodzimego wojskowego ustawodawstwa jest niemożliwe. Odmienność wojskowych warunków polegała jednak na tym, że a priori odrzucono możliwość obowiązywania $\mathrm{w}$ armii różnych aktów prawnych z zakresu procedury i ustroju, w zależności od obszaru państwa. Byłoby to niezgodne $\mathrm{z}$ dążeniem do jednolitości w ramach sił zbrojnych, a ta jak nigdy przedtem była konieczna.

$\mathrm{Z}$ tych wszystkich powodów wybrano jedną ustawę z zakresu organizacji i postępowania przed sądami wojskowymi. Tym aktem miała być austro-węgierska ustawa wojskowego postępowania karnego dla wspólnej siły zbrojnej z 1912 r. ${ }^{29}$ Był to wówczas najnowocześniejszy akt prawny tego typu ${ }^{30}$. Co więcej, postępowanie urządzone austriacką ustawą było znane znacznej grupie prawników wojskowych, wywodzącym się zwłaszcza z kręgu legionów Piłsudskiego. Przyjęty w niej model kasacyjny postępowania karnego rodził również nadzieje na szybkie i sprawne sądownictwo wojskowe, dostosowane do organizacji terytorialnej poszczególnych jednostek armii.

Ustawa lipcowa stanowiła regulację ramową, jedynie upoważniającą rząd do wydania stosownych rozporządzeń, co też nastąpiło dopiero 10 maja 1920 r. Akt wówczas wydany nosi tytuł „Rozporządzenie Rady Ministrów z dnia 10 maja 1920 roku w przedmiocie wprowadzenia w życie na obszarze Rzeczypospolitej ustawy wojskowego postępowania karnego dla wspólnej siły zbrojnej z dnia 5 lipca 1912 roku" $^{\prime 3}$. Kontrowersjom co do mocy obowiązującej tego aktu, zwanego w literaturze potocznie „rozporządzeniem majowym”, poświęcono osobną uwagę, w tym miejscu natomiast należy wskazać, że implementacja do polskiego porządku prawnego obcego prawa odbyła się bez większych zmian o charakterze systemowym.

Ze skromnego, bo liczącego nieco ponad stronę uzasadnienia tego rozporządzenia oraz wypowiedzi w literaturze międzywojennej wynika także kilka dalszych kwestii, które warto przytoczyć, a mianowicie:

1) jego projekt powstał w Oddziale VI Prawnym Ministerstwa Spraw Wojskowych, ale był konsultowany z Ministerstwem Sprawiedliwości ${ }^{32}$;

${ }^{29}$ Austr. Dz. Ustaw Państwa z 1912 r., nr 130 (Tekst w języku polskim dostępny pod adresem $<$ http://jbc.bj.uj.edu.pl/dlibra/publication/227924?tab=1> [dostęp: 22.06.2014]).

${ }^{30}$ L. Sianicki, Na marginesie naszych prac ustawodawczych (Projekt prawa o ustroju sadów wojskowych), „Wojskowy Przegląd Prawniczy” (1934), nr 3, s. 20; zob. także J. Krzemieński, O celowości postępowania w sądownictwie wojskowym, „Wojskowy Przegląd Prawniczy” 1930, nr 3, s. 2.

31 Dz. U. z 1920 r., nr 59, poz. 368.

32 Projekt zmian w ustawie wojskowego postępowania karnego opracowany przez majora Grosickiego oraz projekt przepisów o właściwości sądów wojskowych autorstwa majora Mecnarowskiego (CAW, Oddział VI Prawny, Ministerstwo Spraw Wojskowych, sygn. I.300.12.21). 
2) głównym referentem projektu, z ramienia Ministerstwa Spraw Wojskowych był gen. dr Emil Mecnarowski ${ }^{33}$;

3) przepisy przechodnie wprowadzające austriacką procedurę podzielone były na dwa działy: organizacyjny (ustrojowy) i właściwe przepisy przechodnie. Te pierwsze wchodziły w miejsce dotychczas obowiązujących norm wynikających z dekretu styczniowego, ewentualnie odpowiednich przepisów ustawy z 1912 r.; te drugie $\mathrm{z}$ kolei - odnoszące się do postępowania w sądach wojskowych - ujęto w osobny dział, albowiem nie dały się inkorporować do ustawy austriackiej ze względu na różnice organizacyjne polskiego i austriackiego porządku prawnego oraz konieczność dokonania uzgodnień dzielnicowych ustaw karnych materialnych z niemieckim wojskowym kodeksem karnym;

4) z dekretu o tymczasowej organizacji sądowej Wojska Polskiego przeniesiono i uzgodniono przepisy o oficerskim korpusie sądowym, prokuratorach wojskowych, oficerach sądowych i ich odpowiedzialności dyscyplinarnej ${ }^{34}$.

Sam tok postępowania karnego przewidzianego „rozporządzeniem majowym” nie odbiegał zasadniczo od tego, jaki był przewidziany we wzorcu, a więc austriackiej ustawie wojskowego postępowania karnego z 1912 r. Niewątpliwym jednak osiągnięciem polskich oficerów prawników było wzmocnienie pozycji niezawisłego sądu, poprzez oddanie kierownictwa rozprawy w ręce przewodniczącego składu, a nie jak to przewidywał austriacki proces wojskowy, w ręce przedstawiciela dowódcy $^{35}$. Udział czynnika wojskowego w postępowaniu pozostał jednak nadal istotny za sprawą instytucji właściwego dowódcy i jego uprawnień względem poczynań prokuratora wojskowego. Jeśli jednak odseparujemy rozwiązania prawne właściwe tylko dla wojska, to otrzymamy procedurę odpowiadającą tej funkcjonującej w sądach karnych byłego zaboru austriackiego. Niewątpliwie bowiem austriacka wojskowa procedura z 1912 r. była oparta na założeniach powszechnej regulacji z $1873 \mathrm{r}$.

„Rozporządzenie majowe” stanowiło zwieńczenie dążeń unifikacyjnych w zakresie wojskowego postępowania karnego ${ }^{36}$. W założeniu ówczesnego ustawodawcy miało to być rozwiązanie tymczasowe, aż nastąpi moment bardziej sprzyjający pracom kodyfikacyjnym. Jak się jednak w praktyce okazało, obowiązywało ono w polskim sądownictwie wojskowym blisko siedemnaście lat ${ }^{37}$.

33 J. Adamus, Oskarżyciel prywatny i pokrzywdzony w wojskowym prawie karnym, „Wojskowy Przegląd Prawniczy” (1928), nr 4, s. 13; L. Kania, Generalicja wojskowej stużby sprawiedliwości II Rzeczypospolitej (1918-1945), „Wojskowy Przegląd Prawniczy” (2002), nr 3, s.155.

${ }^{34}$ AAN, Prezydium Rady Ministrów w Warszawie, zespół 8, mikrofilm 20054, k. 401-402.

35 J. Raczek, Instytucja właściwego dowódcy, „Wojskowy Przegląd Prawniczy” (1928), nr 3, s.18.

36 J. Muszyński, Początki Sit Zbrojnych II Rzeczypospolitej, „Wojskowy Przegląd Prawniczy” (1968), nr 4, s. 498-500; J. Krzemieński, O celowości..., s. 1-3; S.M. Przyjemski, Prawo karne wojskowe, Gdańsk 1999, s. 16-17.

37 Ustawę z dnia 28 października 1925 r. w sprawie zmiany rozporządzenia Rady Ministrów z dnia 10 maja 1920 r. w przedmiocie wprowadzenia w życie na obszarze Rzeczypospolitej ustawy 
V. Podejmując kwestię powstawania źródeł wojskowego procesu karnego w Polsce okresu międzywojennego nie sposób pominąć spostrzeżenia Stanisława Śliwińskiego w przedmiocie formalno-prawnej podstawy ich obowiązywania ${ }^{38}$. Problem dotyczy tego, czy rozporządzenie Rady Ministrów z 10 maja 1920 r. zostało wydane $\mathrm{w}$ terminie wynikającym $\mathrm{z}$ delegacji ustawowej, której podstawa znajdowała się w ustawie z dnia 29 lipca 1919 r., czy nie. „Ustawa lipcowa” przewidywała bowiem termin 4 miesięcy na wydanie rozporządzenia, który następnie przedłużono o dalsze 3 miesiące ${ }^{39}$.

Wątpliwości wynikały bez wątpienia z faktu, że sam projekt rozporządzenia został przedstawiony Radzie Ministrów jako wniosek nadzwyczajny (poza porządkiem obrad) przez Ministra Spraw Wojskowych gen. por. Józefa Leśniewskiego dopiero w dniu 10 maja $1920 \mathrm{r}$. Z protokołu posiedzenia wynika ponadto, że projekt został ,przyjęty w zasadzie”, a wprowadzenie poprawek szczegółowych w porozumieniu z Ministerstwem Spraw Wojskowych i Ministerstwem Sprawiedliwości powierzono Prezydium Rady Ministrów ${ }^{40}$. Z kolei z informacji Ministra Spraw Wojskowych gen. por. Kazimierza Sosnkowskiego do marszałka Sejmu Ustawodawczego Wojciecha Trąmpczyńskiego z dnia 2 marca 1921 r. wynika, że ostateczny tekst tego aktu Rada Ministrów przyjęła dopiero 19 maja $1920 \mathrm{r}^{41}$ Termin wydania jednak upływał 12 maja, a ogłoszenie, a zatem „wydanie”, jak słusznie twierdzi Śliwiński, nastąpiło dopiero 22 lipca. Wspomniany autor był zdania, że termin ten nie został dochowany. Co jednak istotne, S. Śliwiński scharakteryzował stan prawny, jaki w tej sytuacji powstał. Jego zdaniem w przypadku przepisów wojskowego postępowania karnego obowiązujących w okresie od 1920-1937 r. mieliśmy do czynienia albo z „dorozumianą legalizacją” przepisów wdrożonych do porządku prawnego z naruszeniem właściwego trybu, albo z „dorozumianą autentyczną wykładnią" pojęcia „wydawać” użytego w art. 5 ustawy lipcowej ${ }^{42}$.

wojskowego postępowania karnego (Dz. U. z 1925 r., nr 119, poz. 858), na mocy której przemianowano dotychczasowe sądy załogowe na wojskowe sądy rejonowe, a sądy okręgów generalnych na wojskowe sądy okręgowe; rozporządzenie Prezydenta RP z 22 marca 1928 r. w sprawie Kodeksu karnego wojskowego (Dz. U z 1928 r., nr 36, poz. 328); ustawę z dnia 21 stycznia 1932 r. w sprawie zmiany rozporządzenia Rady Ministrów z dnia 10 maja 1920 r. w przedmiocie wprowadzenia w życie na obszarze Rzeczypospolitej ustawy wojskowego postępowania karnego (Dz. U. z 1932 r., nr 19, poz. 118).

${ }^{38}$ S. Śliwiński, Proces karny. Czesść ogólna, Warszawa 1936, s. 119.

39 Dz. U. z 1920 r., nr 6, poz. 39.

40 AAN, Prezydium Rady Ministrów w Warszawie, zespół 8, mikrofilm 20054.

${ }^{41}$ AAN, Biuro Sejmu RP w Warszawie, zespół 5, Akta Komisji Wojskowej. Prawo Karne Wojskowe. Marynarka Wojenna. Demobilizacja Koni z Armii. Ustawy. Korespondencja 1920-1921, sygn. 37.

${ }^{42}$ S. Śliwiński, Proces ..., s. 119. 
Data wejścia w życie rozporządzenia nie przedstawiała się przejrzyście. Art. 185 tego aktu stanowił, że miało to nastąpić w terminie 6 tygodni od dnia ogłoszenia. Z kolei art. 1 rozporządzenia Rady Obrony Państwa z dnia 15 lipca 1920 r. postanowil, że natychmiast po jego ogłoszeniu, z wyjątkiem postanowień odnoszących się do sądów załogowych ${ }^{43}$. Co więcej, na mocy kolejnego rozporządzenia Rady z dnia 4 września 1920 termin 6-tygodniowy odnoszący się do sądów załogowych odroczono na okres trzech miesięcy od dnia ogłoszenia aktu zmieniającego $^{44}$. Z tego względu wejście w życie wszystkich postanowień „rozporządzenia majowego" należy określić na dzień 24 grudnia $1920 \mathrm{r}^{45}$

Stan prawny był zatem wyjątkowo skomplikowany, a moc obowiązująca ówczesnych przepisów wojskowego prawa formalnego wątpliwa. Sytuację tego rodzaju da się jednak wytłumaczyć. Po pierwsze, wydanie i ogłoszenie „rozporządzenia majowego" przypadło na okres najkrytyczniejszy dla Polski po 1918 r., a to w związku ze zbliżającymi się wojskami bolszewickimi do Warszawy ${ }^{46}$. Minister Spraw Wojskowych przedstawił projekt rozporządzenia poza porządkiem obrad, w trybie nadzwyczajnym, co może wskazywać, że do ostatniej chwili pracowano nad nim, mając inne ważniejsze zadania do realizacji. Na fakt ten wskazuje dobitnie także mjr Władysław Pilecki, stwierdzając, że akt ten opracowywano w warunkach najmniej sprzyjających, w okresie toczącej się wojny w chwili, kiedy organizacja sił zbrojnych nie była ustalona nawet w zasadniczych zarysach ${ }^{47}$. Po drugie, prawnicze środowiska wojskowe okresu międzywojennego nie ukrywały przekonania, że kolegialny (parlamentarny i rządowy) tryb pracy nad prawem wojskowym nie odpowiadał potrzebom sprawnej regulacji stosunków $\mathrm{w}$ armii. Nie może zatem dziwić fakt, że z chwilą uzyskania przez prezydenta możliwości wydawania rozporządzeń z mocą ustawy, a następnie dekretów o tym samym charakterze, w prawodawstwie wojskowym okresu międzywojennego zaznaczył się bardzo wyraźny postęp ${ }^{48}$. Uzyskanie przez głowę państwa powyższych uprawnień zostało przez wojskowych prawników przyjęte nie tylko z zadowoleniem, co z pewną ulgą i nadzieją na lepszą przyszłość prawodawstwa wojskowego ${ }^{49}$.

${ }^{43}$ Dz. U. z 1920 r., nr 60, poz. 372.

${ }^{4}$ Dz. U. z 1920 r., nr 90, poz. 594.

45 J.M. Skelnik, Organizacja i właściwość wojskowych sąów admiralskich i marynarskich w latach 1920-1939, „Studia Iuridica Toruniensia” 7 (2010), s. 134.

${ }^{46}$ Ibidem, s. 145.

47 W. Pilecki, Najistotniejsze zmiany $w$ wojskowym prawie procesowym, „Wojskowy Przegląd Prawniczy" (1936), nr 4, s. 26.

${ }^{48}$ Nowela sierpniowa z 2 sierpnia 1926 r. (Dz. U. z 1926 r., nr 78, poz. 442) oraz Konstytucja kwietniowa z 23 kwietnia 1935 r. (Dz. U. z 1935 r., nr 30, poz. 227).

${ }^{49}$ M. Buszyński, Polskie ustawodawstwo wojskowe, „Wojskowy Przegląd Prawniczy” (1928), nr 2, s. 18-19. 
Pomimo wyraźnych wątpliwości co do legalności obowiązywania przepisów wojskowego postępowania karnego zawartych w rozporządzeniu Rady Ministrów z 10 maja 1920 r. funkcjonowały one, aż do dnia 31 grudnia 1936 r. Wszystkie kolejno wydawane akty prawne, tak wojskowego prawa karnego materialnego, jak i procesowego, poprzez odwołanie się w przepisach przechodnich do „rozporządzenia majowego" dokonywały, jak słusznie zauważył S. Śliwiński, swoistej jego „legalizacji”50. Nie miała z tym problemu również Komisja Wojskowa Sejmu $\mathrm{RP}$, która w toku prac nad kolejnymi jego poprawkami odnosiła się do niego jako prawa obowiązującego ${ }^{51}$.

VI. Prace nad pierwszym w historii Polski nowoczesnym kodeksem wojskowego postępowania karnego przybrały odmienny od procedury powszechnej charakter. Za „winnych” takiego stanu rzeczy należy uznać zarówno przedstawicieli wojskowej służby sprawiedliwości, jak i przedstawicieli nauki powszechnego prawa i procedury karnej, którzy nie byli specjalnie zainteresowani prawem wojskowym ${ }^{52}$. Jak przekonuje kpt. Antoni Łukasik: „Na podstawie przeglądu czasopism fachowych i zaobserwowanych bezpośrednio w codziennym życiu faktów zauważyć można, że zainteresowanie się świata prawniczego sądownictwem wojskowym polskim jest niewielkie"53. Fakt ten musiał być powodem, dla którego, w duchu informacyjnym i edukacyjnym, Departament Sprawiedliwości Ministerstwa Spraw Wojskowych w 1938 r. wydał broszurę pt. „O wymiarze sprawiedliwości w Wojsku".

Małe zainteresowanie to również efekt podejścia wojska do kwestii regulowania takich kwestii, jak prawo czy procedura karna. I tu „wina” leży po stronie środowiska wojskowych prawników. Otóż - jak podaje z kolei płk Leopold Sianicki - zapatrywanie wojska było inne niż to w obszarze prawa i procedury karnej powszechnej. Przede wszystkim nie powołano żadnej komisji na wzór Komisji Kodyfikacyjnej RP dla opracowania stosownych ustaw ${ }^{54}$. Co więcej, prace nad projektami ustaw w zakresie ustroju, jak i procedury nie były poprzedzone jakąś szerszą publiczną dyskusją, z którą mieliśmy do czynienia chociażby w przypadku powszechnego kodeksu karnego z 1932 r. czy kodeksu postępowania karnego z 1928 r. Co równie ważne, w środowisku wojskowych prawników dostrzegalne

${ }^{50}$ Zob. art. 152 i 153 rozporządzenia Prezydenta Rzeczypospolitej z dnia 22 marca 1928 r. w sprawie Kodeksu karnego wojskowego (Dz. U. z 1928 r., nr 36, poz. 328).

${ }^{51}$ AAN, Biuro Sejmu R.P, Protokoły posiedzeń Sejmowej Komisji Wojskowej, Okres III 19301935, sygn. 23.

52 A. Lityński, Dwa kodeksy..., s. 215.

53 A. Łukasik, O znajomość polskiego sądownictwa wojskowego, „Głos Sądownictwa” (1938), nr 7-8, s. 669.

${ }^{54}$ L. Sianicki, Na marginesie..., s. 2. 
było odmienne podejście do kwestii materialnoprawnych z jednej strony, a proceduralno-ustrojowych z drugiej. Przygotowanie wojskowego kodeksu karnego materialnego z 1932 r. wojskowa służba sprawiedliwości traktowała jako zadanie honorowe, na co wskazują badania Leszka Kani ${ }^{55}$.

$\mathrm{Z}$ ustrojem i procedurą było inaczej. Można odnieść wręcz wrażenie, że te kwestie traktowano drugorzędnie, trochę z przyzwyczajenia do austriackich przepisów, a trochę z obawy przed wyprzedzaniem rozwiązań prawnych projektowanych dla sądownictwa powszechnego ${ }^{56}$. Co więcej, brak było stałego zaplecza dyskusyjnego, na którego forum możliwe byłoby wymienianie poglądów. Działalność Sekcji Prawniczej Towarzystwa Wiedzy Wojskowej oraz jej terenowych jednostek przy wojskowych sądach okręgowych, przynajmniej do pojawienia się „Wojskowego Przeglądu Prawniczego”, wyglądała bardzo skromnie. Jak stwierdził gen E. Mecnarowski, do tego momentu wojskowe środowiska prawnicze wydawały się obojętne na zagadnienia prawa wojskowe ${ }^{57}$. Dopiero reforma Towarzystwa, której naczelnym efektem stało się powstanie wspomnianego kwartalnika spowodowała, że w poszczególnych jego terenowych jednostkach chętniej wygłaszano referaty, podejmowano dyskusję w przedmiocie obowiązującego ustawodawstwa oraz omawiano artykuły o tematyce prawniczej pojawiające się w czasopismach fachowych ${ }^{58}$.

W dziedzinie procedury karnej było już jednak za późno na rewolucyjne rozwiązania. Powszechny kodeks postępowania karnego był już gotowy i czekał tylko na jego ewentualną adaptację w sądownictwie wojskowym. Nie dla wszystkich w wojskowym środowisku prawniczym było to rozwiązanie właściwe, gdyż przynajmniej w opinii płk. L. Sianickiego wojskowa służba sprawiedliwości powinna była rozpocząc starania o rodzime ustawodawstwo właśnie od procedury. Przeciwne rozwiązanie ocenił jako niesłuszne i przypadkowe ${ }^{59}$.

Pewne istotne okoliczności wyjaśniające taki stan rzeczy zawdzięczamy również mjr. W. Pileckiemu, który wskazał, że o ile w zakresie prawa karnego wojskowego materialnego, zgodnie z zasadą stwarzania jak najmniejszych różnic między żołnierzem a resztą obywateli, „wyprzedzenie” kodyfikacji wojskowej przez kodyfikację powszechną było wymagane, o tyle na gruncie ustrojowo-procesowym ta kwestia powinna wyglądać inaczej. W tym zakresie niesłusznie obawiano się eksperymentów, możliwej niezgodności z późniejszą procedurą karną powszech-

55 L. Kania, Przestępstwa ..., s. 199-202.

${ }^{56}$ W. Pilecki, Najistotniejsze..., s. 24-25.

57 J. Zawistowski, Działalność sekcji i podsekcji prawniczych w okresie 1918-1928, „Wojskowy Przegląd Prawniczy" (1928), nr 8-10, s. 44-45.

${ }^{58}$ Z działalności Sekcji Prawniczej T.W.W., „Wojskowy Przegląd Prawniczy” (1938), nr 2, s. $69-72$.

${ }^{59}$ L. Sianicki, Na marginesie..., s. 1-2. 
ną, czy wreszcie braku dostosowania do warunków wojskowych. Dlatego i w tym obszarze zdecydowano się na czekanie, aby po wydaniu ustaw powszechnych przystąpić do ich zbadania pod kątem możliwości ich zastosowania w zasadniczych kwestiach $^{60}$. Dla mjr. W. Pileckiego nie było to właściwe podejście. Podzielał on zdanie płk. L. Sianickiego, że regulacja trybu ścigania przestępstw powinna wyprzedzać regulacje materialne ${ }^{61}$.

Obawa przed „eksperymentowaniem” wydaje się tym bardziej intrygująca, że jak powszechnie wiadomo, kodeks postępowania karnego z $1928 \mathrm{r}$. z początkiem lat trzydziestych został gruntownie znowelizowany, z czego można również wyciągać wniosek, że wojskowa służba sprawiedliwości czekała na ostateczny kształt regulowanej przezeń procedury karnej ${ }^{62}$.

Pewne wyjaśnienie wymienionych zapatrywań zawarł w swoich wykładach płk. S. Lubodzieckiego, w których stwierdził następująco: „System kodeksu wojskowego postępowania karnego w zasadzie jest oparty o system kodeksu postępowania karnego w sądach powszechnych. Dlatego w zasadzie nie będziemy powtarzali i wyjaśniali tego, co jest w k.w.p.k identyczne z k.p.k., i co się słyszy na wykładach o k.p.k. Natomiast zajmiemy się głównie tym, czym k.w.p.k. różni się z uwagi na swoiste właściwości wojska, wywołujące szczególne postanowienia w k.w.p.k., albo odmienne od analogicznych w k.p.k., albo tam zgoła nieznane" ${ }^{63}$.

Z powyższych opinii można wyciągnąć wniosek, że prace i dyskusja na tak szeroką skalę, jak w odniesieniu do k.p.k. z 1928 r., w przypadku k.w.p.k. z 1936 r. nie były konieczne, chociaż zgłaszano takie propozycje ${ }^{64}$. Wszystkie zasadnicze problemy proceduralne zostały wcześniej naświetlone przez naukę prawa procesowego, a sam zasadniczy kierunek modelu polskiego procesu karnego i jego ewolucji, nakreślony w powszechnym k.p.k. i jego kolejnych nowelizacjach. W tej sytuacji Departament Sprawiedliwości MSWojsk. mógł po

${ }^{60}$ W. Pilecki, Najistotniejsze..., s. 23-25.

${ }^{61}$ Ibidem, s. 25.

${ }^{62}$ T. Maresch stwierdził, że ,zasadniczą cechą [kodeksu wojskowego postępowania karnego z 1936 r. - T.Sz.] jest dążenie do upodobania postępowania karnego w wojsku do postępowania przed sądami powszechnymi, w granicach, na jakie pozwalają istota i potrzeby wojska, toteż zupełnie wyraźnie widoczne jest, że kodeks ten wzorowany jest na powszechnym kodeksie postępowania karnego" (T. Maresch, O wymiarze..., s. 14).

${ }^{63}$ S. Lubodziecki, Prawo karne wojskowe. Skrypt z wykładów wygłoszonych na połaczonym kursie Administracyjno-Spolecznym z Ekonomiczno-Prawniczym i Buchalteryjnym w roku akademickim 1942/3, Tel-Aviv 1943, s. 52.

${ }^{64}$ Kierownik wojskowego sądu rejonowego w Toruniu kpt. Kwieciński w opiniach do projektu kodeksu wojskowego postępowania karnego przesłanych 4 lipca 1934 r. do szefa przełożonego WSO Nr VIII w Grudziądzu napisał: „projekt kodeksu wojskowego postępowania karnego nadawałby się raczej do dyskusji zbiorowej, albowiem jest on wiernym obrazem obowiązującego kodeksu postępowania karnego” (CAW, Departament Sprawiedliwości MSWojsk, sygn. I 300.58.208). 
prostu przystąpić do analizy tych rozwiązań z punktu widzenia wojskowego wymiaru sprawiedliwości i ewentualnej ich adaptacji, z uwzględnieniem dotychczasowej praktyki na tle austriackiej ustawy wojskowego postępowania karnego. Tak też się stało.

VII. Zamiar przystąpienia do kodyfikacji wojskowej procedury karnej narodził się wraz z wejściem w życie powszechnego k.p.k. z 1928 r. Kodeks ten stanowił wówczas naturalny punkt odniesienia względem obowiązującej nadal w Wojsku Polskim austriackiej ustawy procesowej z 5 lipca 1912 r. Już w 1929 r., w aktach Komisji Wojskowej Sejmu RP, pojawia się informacja o planach Ministerstwa Spraw Wojskowych odnośnie do przygotowania nowej procedury karnej. Z pewnego zdziwienia członków komisji tym faktem można wnosić, że kwestia ta nie była im bliżej znana, a samą wiadomość traktowano w kategoriach niesprecyzowanej pogłoski ${ }^{65}$. W $1930 \mathrm{r}$. z kolei, pomysł stworzenia nowego wojskowego prawa formalnego, był już znacznie wyraźniej artykułowany, o czym świadczy niezbicie zgłoszony wówczas przez Dowództwo Żandarmerii Wojskowej „Projekt obowiązków i uprawnień żandarmerii, jako organu wykonawczego i pomocniczego sądów i prokuratur wojskowych w ustawie wojskowego postępowania karnego" $"$.

W pierwszej kolejności należało jednak ustalić, jakie ewentualnie problemy wyłaniają się $\mathrm{w}$ dotychczasowej praktyce oraz czy są one do załatwienia wyłącznie w drodze całkowicie nowej kodyfikacji, czy może wystarczy nowelizacja dotychczasowych uregulowań prawnych. Odnosiło się to zarówno do zagadnień materialnoprawnych, jak i procesowych. Tym właśnie celom służył rozkaz Departamentu Sprawiedliwości MSWojsk z dnia 7 sierpnia 1931 r. L.7777/ II/1931r. do jednostek wojskowego wymiaru sprawiedliwości (sądów i prokuratur wojskowych ${ }^{67}$. W odpowiedzi na niego wskazywano na różnorodne problemy, tak proceduralne, ustrojowe, organizacyjne, czy wreszcie terminologiczne. Za najistotniejszy wniosek, jaki pojawia się w tych dokumentach, należy jednak uznać pogląd wyrażony przez prezydenta Najwyższego Sądu Wojskowego gen. Emila Mecnarowskiego. Wedle jego opinii niewskazane było dokonywanie tylko

${ }^{65}$ Pismo posła i członka Komisji Wojskowej W. Trąpczyńskiego z dnia 8 lutego 1929 r. (AAN, Biuro Sejmu RP, Działalność Komisji Wojskowej Okres II 1928-1930, Protokoły, Instrukcje, Dziennik, zespół 5, sygn. 22).

${ }^{66}$ Pismo Dowództwa Żandarmerii z dnia 17 stycznia 1930 r., L.dz. 101/30. Sł w: CAW, Departament Sprawiedliwości MSWojsk, sygn. I 300.58.207.

${ }^{67}$ Raport Najwyższego Sądu Wojskowego w Warszawie z dnia 17 sierpnia 1931 r. L.227/31; raport Prokuratora przy Wojskowym Sądzie Okręgowym Nr 1 w Warszawie z dnia 17 sierpnia 1931 r., L. Dz. 4795/31; raport Prokuratora przy Najwyższym Sądzie Wojskowym z dnia 22 sierpnia 1931 r., L.152/31 (Centralne Archiwum Wojskowe, Departament Sprawiedliwości MSWojsk sygn. I 300.58.207). 
fragmentarycznych zmian w wojskowym ustawodawstwie sądowym, ponieważ to mogło wywołać zamęt ${ }^{68}$. To a contrario oznaczało wybór drogi zupełnie nowej kodyfikacji wojskowej, zarówno w obszarze prawa materialnego, jak i formalnego. Tak też uczyniono, przystępując $\mathrm{w}$ pierwszej kolejności do opracowania nowego materialnego kodeksu karnego wojskowego, który wszedł w życie w 1932 r., aby następnie zając się ustrojem i procedurą, które ze względów podniesionych wcześniej traktowano mniej priorytetowo.

Rozkaz L.7777/II/1931, przeprowadzający coś na kształt monitoringu funkcjonowania wojskowego wymiaru sprawiedliwości, dał możliwość szerokiego spojrzenia na bieżące jego problemy. Pozwolił na zidentyfikowanie tych obszarów, którym w przyszłej procedurze wojskowej należałoby się przyjrzeć dokładniej. To zaowocowało wydaniem przez Naczelnego Prokuratora Wojskowego i ówczesnego szefa Departamentu Sprawiedliwości gen. Józefa Dańca, kolejnego rozkazu, tym razem z dnia 10 listopada 1932 r. L.0200-32, skierowanego do wojskowego środowiska prawniczego. Była to jednocześnie prośba o dalsze zaangażowanie się w prace nad procedurą i ustrojem sądów wojskowych ${ }^{69}$. Jak bowiem stwierdził gen. Daniec: „dotychczasowa współpraca z jednostkami terenowymi była, pomimo nawału ich codziennej pracy, bardzo owocna jeżeli chodzi o wojskowe prawo karne materialne", dlatego liczył na dalszą tego typu współpracę już na gruncie prawa procesowego. Numer porządkowy tego rozkazu, a więc L.0200-32 stał się kancelaryjnym oznaczeniem wszelkich pism dotyczących prac nad wojskową procedurą karną, aż do przygotowania ostatecznego jej projektu. Identyczne oznaczenie posiadają wydane wraz z kodeksem regulaminy dla sądów i prokuratur wojskowych z 1936 i 1937 r.

Rozkaz z 10 listopada nie był tylko pozbawionym merytorycznych odniesień apelem, albowiem gen. J. Daniec sformułował w nim 14 punktów zagadnień, które jego zdaniem należało rozważyć. Ze względu na ich bardzo istotne znaczenie dla dalszych szczegółowych rozważań warto przywołać je w całości. Były one następujące:

„1. Czy skład procedury wojskowej, jej budowę, kolejność rozdziałów i ich treść należy wzorować na procedurze sądowo-karnej w sądach powszechnych?

2. Czy organizację i ustrój sądów rozdzielić od samej procedury, jako osobną ustawę?

3. Jak ująć dochodzenie i śledztwo, czy porzucić obecnie znane i dość zawiłe pojęcie «postępowania badawczego» i zastąpić je pojęciami ścisłymi: dochodzeń i śledztwa?

${ }^{68}$ Raport Najwyższego Sądu Wojskowegow Warszawiezdnia 17 sierpnia 1931 r. L.227/31(CAW, Departament Sprawiedliwości MSWojsk, sygn. I 300.58.207).

${ }^{69}$ CAW, Departament Sprawiedliwości MSWojsk, sygn. I 300.58.208. 
4. Jak uregulować stosunek prokuratorów i sądów wojskowych do dowódcy właściwego oraz zakres władzy tegoż w pokoju i podczas wojny?

5. Jak rozwiązać problem nadzoru nad sądami i prokuratorami - rola Ministra Spraw Wojskowych?

6. Co z rozprawą główną, składem sądów wyrokujących ( 3 czy 5 członków)?

7. Jakie środki prawne - w szczególności, czy zatrzymać zażalenie nieważności, czy też dopuścić apelację, czy też coś kompromisowego, w jakim zakresie i formie?

8. Co z postępowaniem polowym?

9. Co z postępowaniem doraźnym - podczas pokoju i w polu? Jak ująć kwestię kłopotliwego ogłaszania o wprowadzeniu sądów doraźnych?

10. Jak uregulować ustrój prokuratury? Czy i jak ująć kwestię by prokurator przy wyższej instancji mógł występować przed sądami niższej instancji?

11. Co z ustrojem sędziów śledczych? Czy i jak ująć kwestię sędziego śledczego „latającego" tj. takiego, który nie jest związany terytorialnie z sądem?

12. Jak zorganizować sądy rejonowe? Czy i jak doprowadzić do zniesienia tzw. oficerów sądowych, a zastąpić ich żandarmami, o ile nie rozbije się ta koncepcja o niemożliwość powiększenia etatów żandarmerii?

13. Czy zostawić sądy okręgowe i rejonowe terytorialne, czy wprowadzić inne sądy? Co zrobić z prawami dowódcy właściwego terytorialnego na wypadek zniesienia danego sądu?

14. Czy obok istniejących sądów nie stworzyć nowych sądów, np. jednego sądu dla spraw oficerskich itd." ${ }^{\prime 70}$.

Sądy i prokuratury wojskowe miały czas odnieść się do tych zagadnień do 15 grudnia 1932 r., co w związku z koniecznością zwołania posiedzeń sędziów i prokuratorów wojskowych wchodzących w skład okręgowych sekcji prawniczych Towarzystwa Wiedzy Wojskowej wydawało się terminem nierealnym. Co więcej, był to koniec roku, okres wymagający zaangażowania sił i środków w kwestie natury administracyjnej i statystycznej poszczególnych sądów i prokuratur wojskowych. Dlatego rozkazem z grudnia 1932 r. generał Daniec przedłużył ten termin maksymalnie do 1 stycznia 1933 r., z zaznaczeniem, że prosi o jak najszybsze przesyłanie uwag ${ }^{71}$. I tak nie wszyscy zdążyli ${ }^{72}$. Te oko-

${ }^{70}$ Odpis okólnika Departamentu Sprawiedliwości Ministerstwa Spraw Wojskowych z dnia 10 listopada 1932 r. L.0200-32 (CAW, Departament Sprawiedliwości MSWojsk, sygn. I 300.58.208).

${ }^{71}$ Odpis okólnika Departamentu Sprawiedliwości Ministerstwa Spraw Wojskowych z grudnia 1932 r. L.0200-32, [b.daty dziennej] (CAW, Departament Sprawiedliwości MSWojsk, sygn. I 300.58.208).

72 Opinie i uwagi Wojskowego Sądu Okręgowego Nr III w Wilnie z dnia 24 stycznia 1933 r. oraz uwagi Wojskowego Sądu Okręgowego Nr I w Warszawie z dnia 11 stycznia 1933 r. (CAW, Departament Sprawiedliwości MSWojsk, sygn. I 300.58.207). 
liczności pokazują jednak, jak instytucja rozkazu wpływa na usprawnienie pracy legislacyjnej. To również świadczy o tym, że nawet w „biurowym” aspekcie funkcjonowania wojskowego wymiaru sprawiedliwości liczyła się karność i dyscyplina ${ }^{73}$.

Adresaci rozkazu, pomimo bardzo krótkiego czasu, wykonali swoje zadanie, poddając pod dyskusję każdy z jego 14 punktów. Szefowie poszczególnych jednostek prokuratur i sądów wojskowych przesłali następnie wyniki tych dyskusji w formie protokołów do Departamentu Sprawiedliwości Ministerstwa Spraw Wojskowych, nierzadko wraz z osobnymi referatami poszczególnych oficerów ${ }^{74}$.

Napływające z jednostek terenowych do centrali wojskowej służby sprawiedliwości w Warszawie protokoły stanowiły bardzo bogaty, tak pod względem merytorycznym, jak odniesień do praktyki, materiał do wykorzystania przy opracowywaniu projektu kodeksu. Sporne było to, czy jak najdalej usuwać „wojskowość" z rozwiązań procesowych, czy może odwrotnie, podkreślać ją tam, gdzie to niezbędne ze względu na specyfikę wojskowego wymiaru sprawiedliwości ${ }^{75}$. Stanowisko wobec każdego z 14 pytań gen. J. Dańca zależało w istocie jednak od odpowiedzi na pytanie podstawowe: Czy sądownictwo wojskowe jest przede wszystkim sądownictwem - elementem wymiaru sprawiedliwości - czy instytucją wojskową? Zdania były podzielone, chociaż zwolennicy pierwszego założenia stanowili większośćc ${ }^{76}$.

W toku wymiany poglądów pojawiła się również ciekawa koncepcja przygotowania kodeksu wojskowego zawierającego wyłączenie przepisy regulujące tryby postępowania doraźnego i polowego ${ }^{77}$. I chociaż nie została ona, jak wiadomo, ostatecznie zrealizowana, to jednak stanowiła znamienny przejaw dążenia do tego, aby w czasie pokoju w sądownictwie wojskowym obowiązywało prawo funkcjonujące w sądownictwie powszechnym.

73 A. Lityński, Dwa kodeksy..., s. 215.

${ }^{74}$ Pismo szefa Wojskowego Sądu Okręgowego Nr IV w Łodzi z dnia 27 grudnia 1932 r.; pismo szefa Wojskowego Sądu Okręgowego Nr V w Krakowie z dnia 30 grudnia 1932 r.; pismo szefa Wojskowego Sądu Okręgowego Nr VI we Lwowie z dnia 29 grudnia 1932 r.; Pismo szefa Wojskowego Sądu Okręgowego Nr VII w Poznaniu, z dnia 31 grudnia 1932 r.; pismo szefa Wojskowego Sądu Okręgowego nr VIII w Grudziądzu z dnia 14 grudnia 1932 r.; referaty majora Rybickiego i majora Borawskiego w sprawie nowej wojskowej procedury karnej (CAW, Departament Sprawiedliwości MSWojsk, sygn. I 300.58.207).

${ }^{75}$ Opinia Wojskowego Sądu Okręgowego Nr I w Warszawie z dnia 11 stycznia 1933 r.; opinie Wojskowego Sądu Okręgowego Nr IX w Brześciu nad Bugiem z dnia 28 grudnia 1932 r.; opinie Wojskowego Sądu Okręgowego Nr X w Przemyślu z dnia 29 grudnia 1932 r., uwagi Wojskowego Sądu Okręgowego Nr II w Lublinie z dnia 19 grudnia 1932 r.; opinie i uwagi Wojskowego Sądu Okręgowego Nr III w Wilnie z dnia 24 stycznia 1933 r. (ibidem).

${ }_{76}$ Opinia Wojskowego Sądu Okręgowego Nr I w Warszawie z dnia 11 stycznia 1933 r. (ibidem).

77 Tamże. 
Niezależnie od składanych postulatów napływających z terenu, ostateczna decyzja należała do przygotowujących projekt w ministerstwie oficerów, a w szczególności płk. Mariana Buszyńskiego, zastępcy szefa Departamentu Sprawiedliwości MSWojsk ${ }^{78}$. Jak wynika $\mathrm{z}$ jego odręcznych adnotacji na przesłanych do ministerstwa opiniach, każdy pogląd została przez niego rozpatrzony („,iekawa uwaga”, „ważna uwaga”, „uwzgl.”, „nie uwzgl.” itp) ${ }^{79}$.

Projekt kodeksu wojskowego postępowania karnego był gotowy 5 czerwca 1934 r. To właśnie wtedy, w ślad za rozesłanym 22 maja 1934 r. projektem prawa o ustroju sądów wojskowych, do wszystkich instytucji wojskowego wymiaru sprawiedliwości trafił także tekst nowej wojskowej procedury karnej wraz z przepisami wprowadzającymi i przejściowymi. Podobnie jak w fazie wstępnej prac, zapoczątkowanej rozkazem z dnia 10 listopada 1932 r., tak i wówczas wyznaczono sądom i prokuraturom wojskowym termin do nadsyłania uwag, który zakreślono na dzień 10 lipca $^{80}$. Tym razem jednak ze strony Departamentu Sprawiedliwości nie wskazano na żadne szczegółowe kwestie, które należałoby rozważyć. Projekt wojskowego k.p.k. został również rozesłany do poszczególnych ministerstw oraz agend sił zbrojnych, z prośbą o ustosunkowanie się do niego w nieprzekraczalnym terminie $28 \mathrm{dni}^{81}$.

W wykonaniu powyższego polecenia wskazane instytucje nadsyłały swoje stanowiska do projektu, choć niektóre z nich skarżyły się na zbyt krótki czas przewidziany na analizę materiału i przygotowanie wyczerpujących uwag ${ }^{82}$. Wskazywano również na fakt przebywania wielu oficerów Korpusu Sądowego na urlopach, co nie ułatwiało przedstawienia wyczerpujących uwag, zgodnych z rzeczywistymi poglądami oficerów danego okręgu ${ }^{83}$. Część instytucji niezwiązanych choćby pośrednio z wymiarem sprawiedliwości nadsyłało odpowiedź, że nie wnosi uwag, natomiast pozostałe, w tym przede wszystkim Ministerstwo Sprawiedliwości, Ministerstwo Spraw Zagranicznych oraz Ministerstwo Poczty i Telegrafów, przedstawiło obszerniejsze opinie ${ }^{84}$.

${ }^{78}$ Lista starszeństwa Korpusu Oficerów Sądowych, „Rocznik Oficerski” (1928), s. 692.

${ }^{79}$ Ibidem.

${ }^{80}$ Odpis pisma przewodniego z 5 czerwca 1934 r., podpisanego przez płk. M. Buszyńskiego (CAW, Departament Sprawiedliwości MSWojsk, sygn. I 300.58.208).

${ }^{81}$ CAW, Departament Sprawiedliwości MSWojsk, sygn. I 300.58.208.

${ }^{82}$ Szczegółowe uwagi do projektu kodeksu wojskowego nadesłały m.in: Wojskowy Sąd Okręgowy Nr VII w Poznaniu; Wojskowy Sad Okręgowy Nr III w Wilnie; Wojskowy Sąd Okręgowy Nr II w Lublinie oraz Prokuratura przy tym sądzie (CAW, Departament Sprawiedliwości MSWojsk, sygn. I 300.58.208).

${ }^{83}$ Uwagi Wojskowego Sądu Okręgowego Nr I w Warszawie z dnia 14 lipca 1934 r. (CAW, Departament Sprawiedliwości MSWojsk, sygn. I 300.58.208).

${ }^{84}$ Pismo Ministerstwa Skarbu z dnia 30 czerwca 1934 r., nr D,I.43841/1/34; pismo Ministerstwa Rolnictwa i Reform Rolnych z dnia 27 czerwca 1934 r.; pismo Ministerstwa Opieki Społecz- 
Najistotniejsze postulaty zgłosiły jednak ponownie sądy i prokuratury wojskowe, w tym przede wszystkim Prokuratura przy Najwyższym Sądzie Wojskowym $^{85}$. Opinie tych instytucji wskazują, że przesłany im projekt stanowił pewną kompilację kodeksu postępowania karnego z 1928 r. z odpowiednimi przepisami dotychczas obowiązującej w sądownictwie wojskowym austriackiej ustawy procesowej, co tłumaczono względami praktyki i dyscypliny wojskowej ${ }^{86}$.

Ponownie wszelkie zastrzeżenia zostały drobiazgowo zbadane przez płk. M. Buszyńskiego, a część z nich, jak na przykład te nadesłane przez Wojskowy Sąd Okręgowy Nr V w Krakowie, uznane zostały za wręcz bardzo trafne ${ }^{87}$.

Kolejny etap przygotowywania projektu kodeksu wojskowego postępowania karnego nastąpił w sierpniu 1934 r., już w ramach komisji międzyministerialnej ${ }^{88}$. Wówczas w Departamencie Sprawiedliwości Ministerstwa Spraw Wojskowych odbyły się co najmniej dwie konferencje z udziałem przedstawicieli poszczególnych ministerstw, departamentów Ministerstwa Spraw Wojskowych oraz najwyższych wojskowych instytucji służby sprawiedliwości, które wcześniej zgłosiły uwagi do projektu k.w.p.k. ${ }^{89}$ Przewodniczył główny redaktor projektu i wiceszef departamentu pułkownik dr Marian Buszyński ${ }^{90}$. Dyscyplina pracy była również

nej z dnia 26 czerwca 1934 r. nr L. 10g/19-4; pismo Ministerstwa Sprawiedliwości z dnia 5 lipca 1934 r. L.I.K.7210/1/1/34; pismo Ministerstwa Spraw Wojskowych Departamentu Intendentury z dnia 14 lipca 1934 r., nr 4950/Int.Og.21 (CAW, Departament Sprawiedliwości MSWojsk, sygn. I 300.58.208).

${ }^{85}$ Uwagi z dnia 9 lipca 1934 r., L. cz.3841-23a do projektu k.w.p.k nadesłane przez Prokuraturę przy Najwyższym Sądzie Wojskowym, uwagi z dnia 9 lipca 1934 do projektu k.w.p.k nadesłane przez Wojskowego Sądu Okręgowego Nr VIII w Grudziądzu; uwagi z dnia 3 lipca 1934 r. nadesłane przez Wojskowy Sąd Okręgowy Nr IX w Brześciu n/B; uwagi z dnia 11 lipca 1934 r., Prokuratury przy Wojskowym Sądzie Okręgowym Nr IV w Łodzi; uwagi z dnia 10 lipca 1934 r. Dowództwa Żandarmerii (CAW, Departament Sprawiedliwości MSWojsk, sygn. I 300.58.208).

${ }^{86}$ Uwagi do projektu Kodeksu wojskowego postępowania karnego oraz do projektu „Przepisów wprowadzających Prawo o ustroju Sądów Wojskowych oraz Kodeks wojskowego postępowania karnego z dnia 14 lipca 1934 r. (CAW, Departament Sprawiedliwości MSWojsk, sygn. I 300.58.208).

${ }^{87}$ CAW, Departament Sprawiedliwości MSWojsk, sygn. I 300.58.208.

${ }^{88}$ Decyzją Prezydium Rady Ministrów z dnia 2 kwietnia 1919 r. nr 4197/19 ustalono praktykę, wedle której wszelkie wnioski natury ustawodawczej, przed wniesieniem ich do Rady Ministrów, musiały być rozpatrzone na forum międzyministerialnej konsultacji prawnej (CAW, Naczelne Dowództwo Wojska Polskiego, Szefostwo Sądownictwa Polowego, sygn. I.301.21.1).

${ }^{89}$ Protokoły z konferencji, która odbyła się w dniach 9 i 11 sierpnia 1934 r. w Departamencie Sprawiedliwości Ministerstwa Spraw Wojskowych (CAW, Departament Sprawiedliwości MSWojsk, sygn. I 300.58.208).

${ }^{90}$ Pułkownik-audytor; w okresie 24.06.1932 - 30.09.1934 r. zastępca Szefa Departamentu X Sprawiedliwości Ministerstwa Spraw Wojskowych i Naczelnego Prokuratora Wojskowego, współautor wojskowych kodeksów karnych w 1928 i 1932 r. Jeden z najwybitniejszych prawników wojskowych okresu międzywojennego (L. Kania, Stownik biograficzny oficerów-audytorów stużby sprawiedliwości Wojska Polskiego 1914-1945 (cz.2), „Wojskowy Przegląd Prawniczy” (2004), nr 3, s. 111-112). 
obecna i na tym etapie. Pułkownik Buszyński w piśmie skierowanym do wskazanych instytucji dodał bowiem, że nieobecność na konferencji oznacza brak uwag do projektu. Takie postawienie sprawy nie spotkało się z powszechnym zrozumieniem, czego dowodem była krytyczna uwaga Generalnego Inspektoratu Sił Zbrojnych ${ }^{91}$.

W trakcie przeprowadzonych konsultacji i konferencji międzyministerialnych dyskutowano między innymi kwestie immunitetu zakrajowości (postulat Ministerstwa Spraw Zagranicznych), kosztów sądowych, osób mogących być obroncami przed sądami wojskowymi (uwaga zgłoszona przez Generalny Inspektorat Sił Zbrojnych), pozycji procesowej żandarmerii wojskowej (uwagi Dowództwa Żandarmerii) oraz doręczeń (postulaty Ministerstwa Poczty i Telegrafów). Następnie odbyły się jeszcze dwie konferencje, pierwsza z udziałem Ministerstwa Sprawiedliwości i druga z przedstawicielami Najwyższego Sądu Wojskowego i Prokuratury przy NSW. Powodem takiego trybu prac był wzgląd na obszerność uwag, jakie zgłosiły te instytucje $e^{92}$.

Pozostałe prace redakcyjne przeprowadzano w Departamencie Sprawiedliwości MSWojsk i sprowadzały się one nie tylko do redakcji ostatecznego projektu kodeksu wojskowego postępowania karnego, ale również zharmonizowania z nim prawa o ustroju sądów wojskowych ${ }^{93}$. Co więcej, w związku z brakiem czasu na szerszą dyskusję, a tym samym konieczność pozostawienia szeregu spraw bez wyjaśnienia uznano, że zamiast długiego vacatio legis, czas ten poświęci się na opracowanie regulaminów, instrukcji i komentarzy, które wyjaśniałyby pozostałe sporne kwestie ${ }^{94}$. Tak też uczyniono ${ }^{95}$.

Projekt kodeksu wojskowego postępowania karnego został następnie przyjęty na posiedzeniu Rady Ministrów w dniu 26 sierpnia 1936 r. Jego przedstawienie należało do ówczesnego ministra spraw wojskowych gen. dyw. Tadeusza

${ }^{91}$ CAW, Departament Sprawiedliwości MSWojsk, sygn. I 300.58.208.

${ }_{92}$ Uwagi Ministerstwa Sprawiedliwości do projektu kodeksu wojskowego postępowania karnego, zgłoszone pismem z dnia 5 lipca 1934 r. L.I.K.7210/1/1/34; uwagi nad projektem Kodeksu wojskowego postępowania karnego zgłoszone przez Prokuraturę przy Najwyższym Sądzie Wojskowym pismem z dnia 9 lipca 1934 r., L. cz.3841-23a (CAW, Departament Sprawiedliwości MSWojsk, sygn. I 300.58.208).

${ }^{93}$ Protokół z konferencji w przedmiocie ustroju sądów wojskowych, która odbyła się w Departamencie Sprawiedliwości Ministerstwa Spraw Wojskowych 26 lipca 1934 r. (CAW, Departament Sprawiedliwości MSWojsk, sygn. I 300.58.208).

${ }^{94}$ Protokół z konferencji w Departamencie Sprawiedliwości Ministerstwa Spraw Wojskowych z dnia 9 sierpnia 1934 r. (CAW, Departament Sprawiedliwości MSWojsk, sygn. I 300.58.207).

${ }_{95}$ T. Szczygieł, Wojskowe postępowanie karne na ziemiach polskich $w$ latach 1815-1920, [w:] System Prawa Karnego Procesowego. Zagadnienia ogólne, red. P. Hofmański, t. I, cz. 1, Warszawa 2013, s. 328. 
Zbigniewa Kasprzyckiego. Ogłoszenie kodeksu nastąpiło dekretem Prezydenta Rzeczypospolitej z 29 września 1936 r. (Dz. U z 1936 r. nr 76, poz. 537), z mocą obowiązującą od 1 stycznia 1937 r. ${ }^{96}$

VIII. Autentycznej wykładni przepisów kodeksu dokonali jego twórcy - płk M. Buszyński i B. Matzner ${ }^{97}$ w komentarzu, który pojawił się jeszcze przed wejściem kodeksu $\mathrm{w}$ życie ${ }^{98}$. Z prac prawników niezwiązanych $\mathrm{z}$ armią, na uwagę zasługuje z kolei artykuł Stefana Glasera opublikowany na łamach „Gazety Sądowej Warszawskiej”, odznaczający się znacznie bardziej naukowym charakterem niż komentarz twórców kodyfikacji ${ }^{99}$. Jest to poniekąd efekt ówczesnego traktowania kodyfikacji prawa wojskowego, wykluczającego udział osób z zewnątrz $\mathrm{w}$ jego tworzeniu i w efekcie stosunkowo małego zainteresowania tą dziedziną prawa $^{100}$.

Wojskowy k.p.k. był niewątpliwie dziełem praktyków i tworzonym z myślą o praktykach, ale to nie oznacza, że przy jego opracowywaniu nie kierowano się dorobkiem powszechnego procesu karnego. Na podstawie efektów prac legislacyjnych, ale również relacji najwyższych przedstawicieli wojskowej służby sprawiedliwości możemy twierdzić, że wykorzystano materiały Komisji Kodyfikacyjnej Rzeczypospolitej Polskie ${ }^{101}$ oraz dorobek doktryny w postaci prac autorstwa prof. Stefana Glasera, prof. Aleksandra Mogilnickiego, prof. Emila Stanisława Rappaporta i prof. Władysława Woltera. Szeroko również korzystano z dorobku orzecznictwa Sądu Najwyższego. To z kolei oznaczało, że wzorcem dla woj-

${ }^{6}$ W. Pilecki, Najistotniejsze..., s. 24-25; T. Maresch, Przedmowa, [w:] M. Buszyński, B. Matzner, Kodeks wojskowego postępowania karnego i Prawo o ustroju sądów wojskowych z komentarzem, Warszawa 1937; S.M. Przyjemski, Prawo..., s. 19; M. Buszyński, B. Matzner, Stowo wstepne od autorów, [w:] Kodeks..., Warszawa 1937; AAN, Prezydium Rady Ministrów, mikrofilm 20122.

${ }^{97}$ Pułkownik-audytor. od 2.01. 1927 r. kierownik Referatu Kodyfikacyjnego Wydziału II Ustawodawczego Departamentu X Sprawiedliwości Ministerstwa Spraw Wojskowych (L. Kania, Stownik biograficzny oficerów-audytorów stużby sprawiedliwości Wojska Polskiego 1914-1945 (cz.1), „Wojskowy Przegląd Prawniczy” (2003), nr 4, s. 130).

${ }_{98}$ M. Buszyński, B. Matzner, Kodeks wojskowego postępowania karnego i Prawo o ustroju sąów wojskowych z komentarzem, Warszawa 1937.

99 S. Glaser. O kodyfikacji wojskowego prawa karnego, „Gazeta Sądowa Warszawska” (1937), nr 16.

$100 \mathrm{~W}$ prace nad procedurą i ustrojem sądów wojskowych zaangażowani byli ponadto: płk Kazimierz Słowikowski, płk Leopold Sianicki (Dep. Spraw. Wydział I), mjr Witold Pilecki (Dep. Spraw. Wydział III), płk Tadeusz Petrażycki (Najwyższy Sąd Wojskowy) i płk Jan Kamiński z Prokuratury przy Najwyższym Sądzie Wojskowym (Protokół konferencji międzyministerialnej z dnia 9, 11 i 27 lipca 1934 r. w Departamencie Sprawiedliwości Ministerstwa Spraw Wojskowych (CAW, Departament Sprawiedliwości MSWojsk, sygn. I 300.58.208).

101 Projekt ustawy postępowania karnego przyjęty przez Komisję Kodyfikacyjną Rzeczypospolitej Polskiej w dniu 28 kwietnia 1926 r. z uzasadnieniem, [w:] Komisja Kodyfikacyjna Rzeczypospolitej Polskiej, Postepowanie karne, Warszawa 1926, t. I-II. 
skowych kodyfikatorów był kodeks postępowania karnego z 1928 r. Świadczy o tym również systematyka kodeksu wojskowego (pkt 1 rozkazu L.0200-32) oraz treść poszczególnych rozdziałów, które niewątpliwie przejęto w całości z k.p.k. (np. zażalenie). $Z$ kolei konstrukcja postępowania przygotowawczego (śledztwo i dochodzenie), choć przejęta z k.p.k. (pkt 3 rozkazu L.0200-32), to w szczegółach stanowiła już rozwiązania bardziej oryginalne, świadczące bardzo dobrze o tej kodyfikacji (pkt 10 i 11 rozkazu L.0200-32). Dotyczy to zwłaszcza pozycji podejrzanego i jego prawa do obrony formalnej oraz relacji sędziego śledczego względem prokuratora. Wojskowy sędzia śledczy posiadał bowiem większą dozę samodzielności względem prokuratora niż jego odpowiednik w sądownictwie powszechnym. Przepisy o postępowaniu polowym i doraźnym zostały z kolei, bez większych zmian, przejęte $\mathrm{z}$ austriackiej ustawy wojskowego postępowania karnego z 1912 r. (pkt 8-9 rozkazu L.0200-32).

Pomimo że znaczna część przepisów k.w.p.k. stanowiła kontynuację dotychczasowych regulacji, w żadnym jednak względzie nie możemy mówić o automatycznym ich kopiowaniu, czy to z „rozporządzenia majowego”, czy też kodeksu postępowania karnego z 1928 r. Zachowane protokoły, a zwłaszcza dokonywane na ich marginesie notatki płk. M. Buszyńskiego dowodzą jednoznacznie, iż wszystko to, co nie sprawdzało się w praktyce lub nie odpowiadało bieżącym realiom wojska zostało w k.w.p.k. uregulowane odmiennie ${ }^{102}$. Widać to wyraźnie choćby przez pryzmat składów sądów wojskowych od 1937 r., z których to w II instancji wyeliminowano sędziów niefachowych, a w I instancji ich udział znacznie ograniczono ${ }^{103}$. Jako przykład nowości warto również wskazać na model wojskowego postępowania odwoławczego w postaci trybu rewizyjnego oraz odejście od gwarancji zakazu reformationis in peius. Również przyjęcie zasady noviter reperta $\mathrm{w}$ obrębie podstaw wznowienia postępowania karnego było nowością. Austriacka ustawa wojskowego postępowania karnego z 1912 r. i powszechny k.p.k. zawierały w tych materiach zupełnie odmienne uregulowania.

I chociaż tego rodzaju rozwiązania mogą budzić zastrzeżenia w kwestii dostępu do sądu, to jednak warto zaznaczyć, że nie stanowiły one „wynalazku” wojskowej myśli prawniczej. Większość z nich, z ukształtowaniem prawa do instancji odwoławczej i gwarancją zakazu orzekania na niekorzyść skarżącego na czele, stanowiła przedmiot ożywionych dyskusji przedstawicieli nauki powszechnego procesu karnego ${ }^{104}$. Należy również podkreślić, że przyjęcie przez k.w.p.k. syste-

102 S. Lubodziecki, Prawo..., s. 52.

103 W. Pilecki, Najistotniejsze..., s. 27-28.

104 M. Niedzielski, Postulaty reformy procesu karnego (Referat Sprawozdawczy), w: Pamiętniki III Zjazdu Prawników Polskich 5-8 XI 1936 (Katowice-Kraków), cz. 2, Warszawa 1938, s. 15; K. Łada-Bieńkowski, Postulaty reformy procesu karnego (Referat sprawozdawczy na III Zjazd Prawników Polskich Katowice-Kraków 5-8 listopad 1936 r.), Warszawa 1936, s. 6-7; A. Mogil- 
mu rewizyjnego nastąpiło za sugestią Ministerstwa Sprawiedliwości, o ile bowiem struktura sądownictwa powszechnego nie pozwalała na tego rodzaju nowelizację k.p.k., to nieznające sądów apelacyjnych sądownictwo wojskowe nadawało się już do tego doskonale ${ }^{105}$. Postulat gen. J. Dańca (pkt 7 rozkazu L.0200-32), stworzenia pośredniego - między apelacją i kasacją - środka zaskarżenia, został tym samym zrealizowany.

Z punktu widzenia samej techniki legislacyjnej, na podkreślenie zasługuje rozdzielenie zagadnień ustrojowych od ściśle procesowych (pkt 2 rozkazu L.0200-32). Dotychczas te kwestie w wojsku regulowała jedna ustawa. W tym zakresie niewątpliwie podążono tropem regulacji sądownictwa powszechnego ${ }^{106}$. Warto również zauważyć, że k.w.p.k. podobnie jak k.p.k. posiada przepisy poświęcone postępowaniu wykonawczemu (art. 480-554). Są one jednak znacznie bardziej rozbudowane i jak dowodzą archiwalia, nie stworzono z nich odrębnego wojskowego kodeksu karnego wykonawczego tylko dlatego, że powszechny odpowiednik jeszcze nie istniał ${ }^{107}$. Fakt ten świadczy dobitnie o znaczącym wkładzie prawników wojskowych w rozwój prawodawstwa karnego, hamowany jednak z przyczyn od nich niezależnych.

Pomimo swojej specyfiki, objawiającej się w odmiennym traktowaniu niektórych instytucji procesowych i ustrojowych (zwierzchnik sądowo-karny, oficer sądowy, prokurator wojskowy, obrońca wojskowy czy żandarmeria), procedura uregulowana w k.w.p.k. niewątpliwie realizowała założenia tzw. zreformowanego procesu karnego. Konieczność uwzględnienia potrzeb i warunków służby wojskowej w zakresie porządku i dyscypliny starano się pogodzić $\mathrm{z}$ dotychczasowymi doświadczeniami $\mathrm{w}$ zakresie wojskowego wymiaru sprawiedliwości oraz nowoczesnymi prądami polskiego procesu karnego. Proces postępującej integracji procedury karnej wojskowej z powszechnym procesem karnym był już faktem. Było jednak za wcześnie, aby dać temu wyraz w jednym akcie prawnym obowiązującym tak w sądach powszechnych, jak i wojskowych. Potrzeba uregulowania postępowania polowego i doraźnego oraz nadal istotna

nicki, E.S. Rappaport, Kodeks postępowania karnego, cz. II Motywy ustawodawcze, [w:] Ustawy karne Rzeczypospolitej Polskiej, t. I, Warszawa 1929, s. 566-569; E. Szałkowski, Kodeks postępowania karnego. Podręcznik (w zarysie teoret-praktycznym), Lublin 1929, s. 297.

${ }^{105}$ Uwagi Ministerstwa Sprawiedliwości do projektu kodeksu wojskowego postępowania karnego z dnia 5 lipca 1934 (CAW, Departament Sprawiedliwości MSWojsk, sygn. I 300.58.208).

106 Rozporządzenie Prezydenta Rzeczypospolitej z dnia 6 lutego 1928 r. Prawo o ustroju sądów powszechnych (Dz. U. z 1928 r. nr 12, poz. 93); dekret Prezydenta Rzeczypospolitej z dnia 29 września 1936 r. Prawo o ustroju sądów wojskowych (Dz. U. z 1936 r. nr 76, poz. 536).

107 Opinia Wydziału I Departamentu Sprawiedliwości Ministerstwa Spraw Wojskowych w przedmiocie wojskowego kodeksu karnego wykonawczego (CAW, Departament Sprawiedliwości MSWojsk, sygn. I 300.58.208); zob. także M. Buszyński, Kodeks karny wykonawczy jako wyraz nowej systematyki kodyfikacyjnej, ,Wojskowy Przegląd Prawniczy” (1933), nr 3, s. 2-4. 
pozycja procesowa zwierzchnika sądowo-karnego przemawiały jeszcze za odrębnym traktowaniem tej dziedziny prawa. Pozycja armii w państwie również nie była bez znaczenia.

IX. Okres międzywojenny w Polsce, pomimo że trwał stosunkowo krótko, zaowocował wieloma znaczącymi regulacjami prawnymi, zwłaszcza w dziedzinie prawa karnego. Prawo karne powszechne to jednak nie jedyny obszar, który należy mieć na uwadze. Prawodawstwo wojskowe połowy lat trzydziestych również zajmuje istotne miejsce $\mathrm{w}$ procesie kształtowania się rodzimego systemu prawnego, czego kodeks wojskowego postępowania karnego z 1936 r. jest najlepszym przykładem. I chociaż tryb jego opracowywania, jak i przeznaczenie nie sprzyjały podejmowaniu szerszej dyskusji naukowej, to jednak jego powstanie stanowiło bardzo ważny moment $\mathrm{w}$ historii polskiego prawa po $1918 \mathrm{r}$. To właśnie ten akt oraz wydane wraz z nim przepisy wykonawcze i służbowe mogą stanowić po dziś dzień przedmiot rozważań co do przyszłości wojskowego wymiaru sprawiedliwości i to niezależnie od dążeń w integracji prawa wojskowego z prawem powszechnym. Większość bowiem problemów zgłaszanych w toku prac kodyfikacyjnych, a zwłaszcza ujętych w pytaniach gen. J. Dańca i zgłaszanych przez poszczególne sądy wojskowe ma charakter ponadczasowy, o czym bardzo często się zapomina w toku na ogół nieprzychylnej wojskowemu wymiarowi sprawiedliwości dyskusji. Wypaczenia funkcjonowania sądownictwa wojskowego po II wojnie światowej nie mogą jednak przysłaniać nam tego, co stanowi dorobek polskiej wojskowej myśli prawniczej i w istocie dziedzictwo okresu, kiedy armia kojarzona była przede wszystkim jako gwarant niepodległości, a nie przedmiot krytyki.

\author{
UNIFICATION AND CODIFICATION \\ OF THE MILITARY CRIMINAL PROCEDURE \\ IN THE SECOND POLISH REPUBLIC
}

\title{
Summary
}

Numerous changes were made in the Polish legal system in the interwar period. Not only did the unification and codification of common law take place but also of the regulations present in the court-martial. However, the court-martial regulations were compiled in a completely different way. The Codification Commission was not concerned in the issue at all. All of the unification and codification work in the armed forces was completed at the Ministry of Military Affairs.

Since the very beginning of the Polish Republic, there was awareness that one of the priorities of the forming army was the need to unify the military criminal procedure. This goal was achieved relatively fast as it was finished by the mid-1920s. It was possible due 
to the limitation of doctrinal discussions and due to the involvement of a small circle of military attorneys in the process. The criminal procedure of the Austrian military from 1912 was adopted as the unification solution after it was appropriately adjusted to the realities of the system and to the organization of the Polish army.

The codification of the military criminal procedure did not take place until the mid30 s of the $20^{\text {th }}$ century. The development of the code was entrusted to Colonel Marian Buszyński from the Department of Justice of the Ministry of Military Affairs. He prepared the code of military criminal procedure in 1936. It combined the prior experiences of the military justice with the model of the criminal procedure present in common courts.

Despite the indubitable similarities with the common criminal procedure, the military code was an original work. It included numerous and distinct legal solutions. Among them were both the ones which were completely different from the civilian procedure due to the specificity of the army as well as the solutions which functioned previously only in the sphere of doctrinal discussions.

\section{L'UNIFICATION ET LA CODIFICATION \\ DE LA PROCEDURE PENALE MILITAIRE \\ DE LA DEUXIEME REPUBLIQUE DE POLOGNE}

\section{Résumé}

Dans l'entre-deux-guerres, la Pologne a procédé non seulement à l'unification et à la codification des procédures judiciaires du droit commun, mais aussi de celles du système judiciaire militaire. Toutefois, les règlements militaires de procédure étaient élaborés par d'autres moyens. La Commission de codification ne s'occupait pas du tout de cette question.

Tous les travaux d'unification et de codification dans l'armée étaient effectués dans le cadre du Ministère des Affaires Militaires. Dès le premier instant de l'existence de l'État polonais, le besoin d'unifier les procédures pénales militaires est devenu l'une des priorités de l'armée qui se formait. Grâce à la limitation des débats doctrinaux et avec l'engagement d'un cercle restreint de juristes militaires, on a réussi à réaliser cet objectif relativement vite, déjà au milieu de l'année 1920. On a alors adopté, en tant que système d'unification, la procédure pénale militaire autrichienne de l'année 1912, dûment adaptée aux réalités politiques et organisationnelles de l'armée polonaise. La codification de la procédure pénale militaire a été effectuée seulement au milieu des années trente du XXe siècle. L'élaboration du Code a été confiée au colonel Marian Buszyński du Département de la Justice du Ministère des Affaires Militaires. Le Code de procédure pénale militaire rédigé par lui en 1936 associait l'expérience passée de la juridiction militaire avec le modèle de procédure pénale en vigueur dans la juridiction de droit commun. Malgré les ressemblances indiscutables avec la procédure pénale ordinaire, le Code militaire constituait une rédaction originale. L'auteur y a inscrit de nombreuses différentes solutions juridiques, aussi bien celles qui étaient totalement étrangères aux procédures ordinaires en raison de la spécificité de l'armée, que celles qui jusqu'alors fonctionnaient seulement comme considérations d'ordre doctrinal. 
